\title{
Physical activity and overweight among adolescents on the Texas-Mexico border
}

\author{
Adriana Pérez, ${ }^{1,2}$ Belinda M. Reininger, ${ }^{2,3}$ María Isabel Aguirre Flores, ${ }^{4}$ \\ Maureen Sanderson, ${ }^{2,5}$ and Robert E. Roberts ${ }^{6}$
}

Suggested citation Pérez A, Reininger BM, Aguirre Flores MI, Sanderson M, Roberts RE. Physical activity and overweight among adolescents on the Texas-Mexico border. Rev Panam Salud Publica. 2006:19(4):244-52.

ABSTRACT Objective. To investigate differences in associations between physical activity and overweight for students in two adjacent areas on the border between Mexico and the United States of America: students in the city of Matamoros, Mexico, and Mexican-American students in the Lower Rio Grande Valley (LRGV) area of southern Texas. Since the extremely high prevalence of overweight among Mexican-American adolescents is well-recognized, we wanted to determine whether overweight has become a problem among Mexican adolescents as well.

Methods. Students from 6 schools $(\mathrm{n}=653)$, representing $11 \%$ of the ninth-grade students in Matamoros during 2002-2003, and students from 13 high schools $(\mathrm{n}=4736)$, representing 22\% of the ninth-grade students in the LRGV during 2000-2001, completed questionnaires. Polytomous logistic regression was performed to estimate the risk of being at risk for overweight ( $\geq 85$ th percentile to $<95$ th percentile of body mass index (BMI) for age and sex) and the risk of being overweight ( $\geq 95$ th percentile of BMI-for-age and sex) versus normal weight that were associated with measures of physical activity. For simplicity, the classification of normal weight also included underweight.

Results. A higher percentage of adolescents in the LRGV were at risk of overweight $(17 \%)$ in comparison with adolescents from Matamoros (15\%). The percentages of LRGV and Matamoros adolescents who were overweight were identical (17\%). LRGV adolescent boys (OR = $0.87,95 \% C I=0.77-0.98$ ) who participated in team sports were less likely to be at or above the 85th percentile of BMI-for-age and sex. Although of borderline significance, Matamoros and LRGV adolescent boys who participated in physical education classes were less likely to be at risk for overweight. Among neither the Matamoros students nor the LRGV students were any of the various other physical activity categories or levels associated with being at risk for overweight or being overweight.

Conclusions. Nearly one-third of the students in both Matamoros and the LRGV are at risk for overweight or are overweight. Implementation of interventions on healthful dietary choices and participation in physical education classes and sports teams are essential for reducing the extremely high prevalence of overweight among students on both sides of the Texas/Mexico border.

Key words Overweight, obesity, physical fitness, adolescent, Mexican Americans, Mexico, Texas.

\footnotetext{
The University of Texas Health Science Center at Houston, School of Public Health, Division of Biostatistics, Brownsville, Texas, United States of America. Send correspondence to: Adriana Pérez, 80 Fort Brown, SPH Building, Room N2.200, Brownsville, Texas 78520, United States of America; telephone: 956-882-5160; fax: 956-882-5153; e-mail: adriana.perez@utb.edu
}

2 Hispanic Health Research Center, Brownsville, Texas, United States of America.

3 The University of Texas Health Science Center at Houston, School of Public Health, Division of Health Promotion and Behavioral Sciences, Brownsville, Texas, United States of America.

4 Secretaría de Educación de Tamaulipas, Ciudad Victoria, Tamaulipas, México.
5 The University of Texas Health Science Center at Houston, School of Public Health, Division of Epidemiology, Brownsville, Texas, United States of America.

6 The University of Texas Health Science Center at Houston, School of Public Health, Division of Health Promotion and Behavioral Sciences, Houston, Texas, United States of America. 
Health risk behaviors established during childhood create behavioral patterns that extend into adulthood and contribute to leading causes of morbidity and mortality (1). For example, low levels of physical activity established in childhood have been shown to contribute to overweight and obesity among adults (2). In recent years an extremely high prevalence of being at risk of overweight or being overweight among adolescents has been reported in the United States of America and in other nations (2-4). Food consumption (particularly of calorie-dense foods) and lack of physical activity have been associated with obesity, coronary artery disease, and type 2 diabetes (5-8).

Objective 22-6 of the Healthy People 2010 publication (9) establishes guidelines for moderate physical activity among adolescents in the United States, and the 2005 Dietary Guidelines for Americans (10) provides consistent recommendations for children and adolescents. Healthy People 2010 (9) suggests that adolescents engage in moderate physical activity for at least 30 minutes per day on five or more days per week, and in vigorous physical activity that promotes cardiorespiratory fitness for at least $20 \mathrm{~min}$ utes per day three or more days per week. Based on United States national data from the Youth Risk Behavior Survey, the prevalence of moderate physical activity among ninth-grade schoolchildren of all ethnicities was $28.3 \%$ for males and $22.3 \%$ for females (1). The prevalences of moderate physical activity were lower among Hispanic adolescent boys (23.3\%) and girls (20.6\%) (1). A similar pattern was seen for the prevalence of vigorous physical activity, where male $(73.1 \%)$ and female $(63.6 \%)$ ninth-grade schoolchildren of all ethnicities had higher prevalences than did Hispanic males (66.7\%) and females (51.8\%) (1). Limited information has been found concerning the prevalence of physical activity in Mexico. Hernández et al. $(11,12)$ reported 1.8 hours per day ( \pm 1.3 hours per day standard deviation) as the average of moderate and vigorous physical activity combined among schoolchildren 916 years old in Mexico City.
Our study investigated patterns of specific risk behaviors among MexicanAmerican and Mexican youths by gender. The objective of the research was to determine whether an association exists between physical activity and overweight among ninth-grade students in the city of Matamoros, Tamaulipas, Mexico, which is in northeastern Mexico, on the border with the United States. Additionally, we wanted to compare the results from Matamoros with the results for Mexican-American youth living directly across the border in the Lower Rio Grande Valley (LRGV) area of the state of Texas. A strength of this comparison is that most of the students in the LRGV area are of Mexican descent and live in close proximity to Matamoros, thus minimizing cultural and acculturation differences between the two areas. Since the extremely high prevalence of overweight among Mexican-American adolescents is well-recognized, we wanted to determine whether overweight has become a problem among Mexican adolescents as well.

\section{MATERIALS AND METHODS}

\section{Lower Rio Grande Valley survey and participants}

During the 2000-2001 school year the Lower Rio Grande Valley Youth Risk Behavior Survey (LRGV-YRBS) was conducted. The primary objective of the LRGV-YRBS was to determine health risk behaviors that contribute to adolescent morbidity and mortality in the four southernmost counties of Texas (Cameron, Hidalgo, Starr, and Willacy). (This LRGV-YRBS survey was not part of the national YRBS done in the United States.) A full description of the LRGV-YRBS study design, participants, and sample has been provided previously $(13,14)$, so only a brief summary will be given here. Specifically, this survey measured behaviors related to (1) unintentional injuries and violence, (2) tobacco use, (3) drug and alcohol use, (4) sexual behaviors, (5) diet and physical activity, (6) sleep and work patterns,
(7) suicidal thoughts, (8) suicidal behaviors, (9) depression, and (10) anxiety. The LRGV-YRBS questions on unintentional injuries, violence, tobacco use, drug and alcohol use, sexual behaviors, diet, and physical activity were based on the national YRBS (1), which was conducted by the Centers for Disease Control and Prevention (CDC) of the United States.

In the 2000-2001 school year there were over 21500 ninth-graders enrolled in the 40 public high schools in the LRGV area. A sample of 18 public high schools with ninth-grade schoolchildren representative of the LRGV population was selected using a stratified multistage probabilistic sampling design, but 5 of the schools refused to participate. The resulting sample included 5118 respondents from 13 public high schools, representing $24 \%$ of the ninth-grade students. For this study we restricted our analysis to 4736 students (22\% of the ninth-grade students) who reported they were Mexican-American and who did not have missing values on sex, age, and the adjustment variables of student marital status and family standard of living. This study was approved by the University of Texas Health Science Center at Houston's Committee for the Protection of Human Subjects. Passive parental permission was obtained by the school districts prior to conducting the survey. Under the supervision of a moderator, the students answered the self-administered survey questionnaire during regularly scheduled classes. Students had the opportunity to refuse participation, or they could have been absent the day of the survey, which may have contributed to the overall response rate of $67 \%$. Self-reported height and weight, from two of the survey questions, were used to compute body mass index (BMI).

\section{Matamoros survey, participants, and measurement of height and weight}

For the Matamoros survey, we forward-translated the English-language LRGV-YRBS questionnaire into Spanish and then back-translated it into 
English in order to ensure that the Spanish and English versions of the questionnaire were comparable. The Spanish questionnaire was also adapted using the Mexican cultural idiom. The Secretariat of Education of the state of Tamaulipas (Secretaría de Educación de Tamaulipas) added questions on family support, school support and empowerment, religiosity, and housing arrangements. A pilot study was conducted in two schools, and minor modifications were made to improve the readability of the instrument. This instrument is available upon request from the authors.

Matamoros is located across the Rio Grande River from the sister city of Brownsville (Cameron County), Texas. During the 2002-2003 school year there were a total of 28 public and private high schools in Matamoros, with 5762 students in the ninth grade (tercero de secundaria in the Mexican school system). The Secretariat of Education of Tamaulipas provided the sampling frame used to select a representative sample of ninth-grade students. Unlike the LRGV-YRBS, the sampling frame included both public schools and private schools.

The Matamoros high schools were stratified using the total number of ninth-grade classes in each school: those with 10 or more ninth-grade classes, and those with fewer than 10 ninthgrade classes. The sampling design implemented for this cross-sectional survey was a two-stage stratified cluster design. The sample size required for this survey was estimated using as main outcomes of interest the prevalence of violent behavior and drug use among students. These behaviors, estimated to have a prevalence of $10 \%$, were chosen because they were expected to have the lowest prevalence of risky behaviors. Thus, if the sample size was sufficient to detect differences in these risky behaviors, it would be sufficient to detect differences in all risky behaviors. Assuming a type I error level of $0.05 \%$ and a precision level of $25 \%$ from the true population value, we required a minimum of 623 students.

Using an estimated participation rate of $68 \%$, we randomly selected six high schools that had fewer than 10 ninth-grade classes and two high schools that had 10 or more ninthgrade classes. Seeking to obtain similar weights across strata of classes, we selected all ninth-grade classes from the high schools with fewer than 10 ninthgrade classes. Two high schools with fewer than 10 ninth-grade classes refused to participate. The final sample included 669 respondents, from 6 of the 28 high schools, representing $12 \%$ of ninth-grade students in Matamoros during 2002-2003. For this manuscript we restricted our analysis to 653 students $(11 \%)$ who did not have missing values on age and the adjustment variables of student marital status and family standard of living.

The consent form for participation in this study was approved by the Committee for the Protection of Human Subjects at the University of Texas Health Science Center at Houston. The form required the active consent of a parent or guardian. Students who did not receive parental authorization or who forgot to bring the signed consent form to school were given other written activities (e.g., crossword puzzles) to do while the students who had consent completed the survey. Under the guidance of a trained moderator the students answered the selfadministered questionnaire during a regularly scheduled class. The overall response rate was $58 \%$.

Using a standard protocol, trained project staff measured the height and weight of each student, in a predesignated area in each school. The adolescents removed any heavy clothes and their shoes before being measured. Height was measured to the nearest 0.1 $\mathrm{cm}$ with the portable PE-AIM-101 stadiometer unit (Perspective Enterprises, Portage, Michigan, United States). Weight was measured to the nearest $0.1 \mathrm{~kg}$ with the portable BWB-800S digital scale with a remote display (Tanita, Arlington Heights, Illinois, United States) calibrated to $250 \mathrm{lb}(113 \mathrm{~kg}$ ) before each series of measurements. Project staff wrote both measures directly on the student questionnaires.

For quality control we randomly selected $7 \%$ of the students to remeasure.
The Lin concordance correlation coefficient for agreement $(15,16)$ was 0.976 for height and 0.993 for weight. The Pearson correlation coefficient, a measure of precision, was 0.977 for height and 0.994 for weight. The bias correction factor, a measure of accuracy, was 0.998 for height and 0.999 for weight. For all survey respondents in Matamoros, body mass index (BMI) was calculated using the standard equation of weight in kilograms divided by the square of the height in meters.

\section{Lower Rio Grande Valley and Matamoros BMI classification and questions about personal life situation, physical activity, and attempted weight control}

Using the current United States BMI-for-age and sex growth charts (http://www.cdc.gov/growthcharts/), the adolescents in the LRGV and in Matamoros were classified as normal weight ( $<85$ th percentile), at risk of overweight ( $\geq 85$ th percentile to $<95$ th percentile), or overweight ( $\geq 95$ th percentile). For simplicity, our classification of normal weight included underweight.

Two questions on personal life situation were examined. Students' marital status was asked as "Some people get married before they turn 18. Which of the following best describes you?". We used the following categories of response: (1) single, never married; (2) living with a partner or significant other, but not married; (3) married; and (4) separated, divorced, or widowed. The family's standard of living was asked as "What best describes your family's standard of living? Economically, would you say your family is. ..". We used the following categories of response: (1) very well-off, (2) living very comfortably or just getting along, and (3) nearly poor or poor.

Five measures of physical activity were examined and dichotomized as physically active or inactive. The criteria for active were: (1) vigorousintensity physical activity in three or more sessions per week, lasting at least 20 minutes each; (2) moderate- 
intensity physical activity in five or more sessions per week, lasting at least 30 minutes each; (3) strength training in three or more sessions per week; (4) enrollment in physical education classes; and (5) participation on one or more sports teams.

One question was used to assess television viewing: "On an average school day, how many hours do you watch TV?". We dichotomized it as three or more hours per day during an average school day versus less than three hours per day.

Six measures of attempted weight control were examined with a time frame of "during the past 30 days." The six questions used for assessment were: (1) "Did you exercise to lose weight or to keep from gaining weight? (yes/no)"; (2) "Did you eat less food, fewer calories, or foods low in fat to lose weight or to keep from gaining weight? (yes/no)"; (3) "Did you go without eating for 24 hours or more (also called fasting) to lose weight or to keep from gaining weight? (yes/no)"; (4) "Did you take any diet pills, powders, or liquids without a doctor's advice to lose weight or to keep from gaining weight? (Do not include meal replacement products such as Slim.Fast) (yes/no)"; (5) "Did you vomit or take laxatives to lose weight or to keep from gaining weight? (yes/no)"; and (6) "Which of the following are you trying to do about your weight? (lose weight, gain weight, stay the same weight, or I am not trying to do anything about my weight)".

\section{Data management and statistical analysis for the Lower Rio Grande Valley and for Matamoros}

The LRGV students completed Scantron forms, which were scanned for data entry. The Matamoros questionnaires were scanned using Snap version 6.0 software (17). Verification and inconsistencies were assessed using SAS version 9.1 software (18). We computed probabilistic sampling weights to account for differential inclusion probabilities in the cluster sampling at the school level. Sampling weights were the inverse of the selection probability for the sampling ratio at each stage of selection. In the LRGV, ratio adjustment for ninth-grade students enrolled in all public high schools was implemented using the total school enrollment. In Matamoros, nonresponse adjustment and ratio adjustment for ninth-grade students enrolled in all public and private high schools were implemented using the sampling frame provided. The nonresponse adjustment accounted for students who refused to complete the questionnaire and students who were absent the day of the survey. The ratio adjustment was done to ensure that the gender composition of the samples was the same as that of the total school enrollment in the LRGV and Matamoros. Sample design characteristics, including the clustering of students within schools and stratification of the sample, were accounted for using the sampling weights. Weighted percentages, means, standard errors, and test statistics were calculated using SUDAAN version 9.0.0 software (19). Polytomous logistic regression analyses were performed to estimate the risk of at risk for overweight ( $\geq 85$ th percentile to $<95$ th percentile of BMI-for-age and sex) and to estimate the risk of overweight $(\geq 95 \mathrm{th}$ percentile of BMI-for-age and sex) versus normal weight. The exposures that were investigated included physical activity, watching television, and attempted weight control. We reported associations for girls and boys separately. All estimates were adjusted for the students' perceptions of their family standard of living and for the students' marital status. The proportional odds ratio assumptions (20) held for these data in the LRGV and Matamoros. For this reason, only one set of odds ratios is presented in our results. For example, this model assumes that the odds of being at risk of overweight compared to being normal weight is proportional to the odds of being overweight compared to being at risk for overweight or being normal weight for a particular independent variable.

\section{RESULTS}

Table 1 presents the demographic characteristics, BMI classification, types and levels of physical activity, number of hours of television watched, and attempts to lose weight among students in Matamoros and in the LRGV. The median age of the adolescents in Matamoros was 14 years, and it was 15 years in the LRGV. There were statistically significant differences between LRGV girls and LRGV boys in marital status $(P=0.002)$. In the LRGV, we observed a greater proportion of adolescents who were married; living with a partner or significant other but not married; or separated, divorced, or widowed than was true in Matamoros. There was no significant difference in marital status between the Matamoros girls and the Matamoros boys. There were statistically significant differences in the family's standard of living between girls and boys in both Matamoros $(P=$ 0.0174) and the LRGV $(P=0.01)$.

The LRGV boys were more likely to be at or above the 85th percentile of BMIfor-age than were the LRGV girls ( $P=$ 0.002) (Table 1). The difference between Matamoros girls and Matamoros boys was not significant $(P=0.072)$ (Table 1 ). The overall prevalence of at risk for overweight was $15 \%$ in the Matamoros students and $17 \%$ in the LRGV students. The overall prevalence of overweight was $17 \%$ in both the Matamoros students and the LRGV students.

Of the Matamoros students, $97.7 \%$ were classified as active in one or more of the physical activity measures, compared with $85.4 \%$ of the LRGV students (Table 1). Just over $7 \%$ of the Matamoros students and just over $9 \%$ of the LRGV students were classified as active on all five measures of physical activity. In both Matamoros and the LRGV, of any of the measures of physical activity, students were the least likely to engage in moderate intensity physical activity. In both Matamoros and the LRGV, adolescent boys were more likely to engage in four measures of physical activity (vigorous, moderate, strength training, and sports-team participation) than were the girls $(P<0.025$ for all $)$. 
TABLE 1. Weighted percentage estimates (with standard error (SE)) of demographic characteristics, physical activities, watching television, and attempting to control weight of ninth-grade school children in Matamoros (Tamaulipas, Mexico), 2002-2003, and in the Lower Rio Grande Valley (Texas, United States of America), 2000-2001,a

\begin{tabular}{|c|c|c|c|c|c|c|c|c|}
\hline & \multicolumn{2}{|c|}{$\begin{array}{c}\text { Matamoros } \\
\text { girls } \\
(n=357) \\
(\mathrm{N}=3074)\end{array}$} & \multicolumn{2}{|c|}{$\begin{array}{c}\text { Matamoros } \\
\text { boys } \\
(n=296) \\
(\mathrm{N}=2574)\end{array}$} & \multicolumn{2}{|c|}{$\begin{array}{l}\text { Lower Rio Grande } \\
\text { Valley girls } \\
(n=2378) \\
(\mathrm{N}=9976)\end{array}$} & \multicolumn{2}{|c|}{$\begin{array}{l}\text { Lower Rio Grande } \\
\text { Valley boys } \\
\begin{array}{l}(n=2358) \\
(\mathrm{N}=9870)\end{array}\end{array}$} \\
\hline \multicolumn{9}{|l|}{ Student's marital status } \\
\hline Single, never married & 94.48 & 0.44 & 92.63 & 1.14 & 80.90 & 0.75 & 75.18 & 1.27 \\
\hline Living with a partner or significant other but not married & 0.93 & 0.77 & 2.75 & 0.89 & 5.75 & 0.41 & 8.54 & 1.13 \\
\hline \multicolumn{9}{|l|}{ Family's standard of living } \\
\hline Very well-off & 3.54 & 0.96 & 4.72 & 1.39 & 15.65 & 1.48 & 18.99 & 1.29 \\
\hline Living very comfortably or just getting along & 91.77 & 0.81 & 84.29 & 2.23 & 81.43 & 1.48 & 76.75 & 1.30 \\
\hline Nearly poor or poor & 4.69 & 0.47 & 11.00 & 2.16 & 2.92 & 0.32 & 4.26 & 0.49 \\
\hline \multicolumn{9}{|l|}{ Body mass index classification } \\
\hline Normal & 71.37 & 1.90 & 64.73 & 3.15 & 71.26 & 0.77 & 60.68 & 1.87 \\
\hline Strength training & 24.58 & 1.93 & 43.84 & 2.55 & 50.69 & 1.84 & 62.72 & 1.57 \\
\hline Physical education class enrollment & 95.72 & 1.51 & 94.84 & 1.68 & 55.24 & 3.76 & 62.01 & 2.29 \\
\hline Sports-team participation & 48.39 & 3.13 & 63.36 & 1.36 & 50.69 & 1.73 & 64.38 & 0.88 \\
\hline All of the five activities & 3.51 & 1.93 & 12.25 & 1.97 & 6.85 & 0.54 & 12.10 & 0.44 \\
\hline \multicolumn{9}{|l|}{ Watching television an average of three or more hours per day } \\
\hline on a school day & 57.12 & 1.31 & 57.89 & 3.75 & 48.96 & 0.72 & 50.76 & 0.90 \\
\hline \multicolumn{9}{|l|}{ Attempted weight control during the preceding 30 days } \\
\hline Exercise to lose weight & 47.24 & 2.58 & 45.88 & 2.38 & 66.77 & 1.49 & 61.64 & 1.21 \\
\hline Eat less food & 43.48 & 1.23 & 35.24 & 3.84 & 51.02 & 0.94 & 30.01 & 0.91 \\
\hline Go without eating for 24 hours or more & 14.57 & 2.49 & 10.06 & 1.74 & 21.55 & 0.95 & 10.15 & 1.21 \\
\hline Take any diet pills, powder, or liquids & 3.60 & 1.26 & 3.41 & 1.78 & 10.30 & 1.03 & 6.74 & 0.72 \\
\hline Vomit or take laxatives & 6.40 & 1.90 & 1.71 & 1.55 & 10.95 & 0.73 & 5.50 & 0.76 \\
\hline \multicolumn{9}{|l|}{$\begin{array}{l}\text { Trying to do something about weight during the preceding } \\
30 \text { days }\end{array}$} \\
\hline
\end{tabular}

Fifty-seven percent of the students in Matamoros and $50 \%$ of the students in the LRGV watched television three or more hours per day during an average school day (Table 1). About $46 \%$ of the students in Matamoros and $64 \%$ of the students in the LRGV had exercised to lose weight or to keep from gaining weight during the 30 days preceding the survey. During the preceding 30 days, the LRGV girls were significantly more likely than were the LRGV boys to have done the following to try to control their weight: (1) exercised to lose weight or to keep from gaining weight $(P=0.011)$; (2) eaten less food, fewer calories, or foods low in fat $(P<0.001)$; (3) gone without eating for 24 hours or more $(P=0.001)$; (4) taken diet pills, powders, or liquids without a doctor's advice $(P=0.036)$; and (5) vomited or taken laxatives $(P=0.001)$. The LRGV girls were significantly more likely than were the LRGV boys to try to lose weight, while the LRGV boys were more likely than were the LRGV girls to try to gain weight $(P=0.002)$. This gender difference on trying to lose weight or to gain weight was not significant among the Matamoros students.

Table 2 presents the adjusted odds ratios (ORs), with 95\% confidence intervals (CIs), from polytomous logistic regression for being at risk of overweight ( $\geq 85$ th percentile to $<95$ th percentile BMI-for-age and sex) and being overweight ( $\geq 95$ th percentile of BMIfor-age and sex) versus normal weight 
TABLE 2. Adjusted odds ratios (ORs) and $95 \%$ confidence intervals (Cls) for being at risk for overweight ( $\geq 85$ th percentile to $<95$ th percentile of body mass index (BMI) for age and sex) and for being overweight ( $\geq 95$ th percentile of BMI-for-age and sex) versus normal weight associated with measures of physical activity, watching television, and attempted weight control in ninth-grade school children in Matamoros (Tamaulipas, Mexico), 2002-2003, and in the Lower Rio Grade Valley (Texas, United States of America), 2000-2001 ${ }^{\mathrm{a}}$

\begin{tabular}{|c|c|c|c|c|c|c|c|c|}
\hline & \multicolumn{4}{|c|}{ Matamoros } & \multicolumn{4}{|c|}{ Lower Rio Grande Valley } \\
\hline & \multicolumn{2}{|r|}{ Girls } & \multicolumn{2}{|c|}{ Boys } & \multicolumn{2}{|c|}{ Girls } & \multicolumn{2}{|r|}{ Boys } \\
\hline & OR & $95 \% \mathrm{Cl}$ & OR & $95 \% \mathrm{Cl}$ & OR & $95 \% \mathrm{Cl}$ & OR & $95 \% \mathrm{Cl}$ \\
\hline \multicolumn{9}{|l|}{ Physical activity } \\
\hline Vigorous & 2.22 & $0.67-7.43$ & 0.92 & $0.53-1.61$ & 1.15 & $0.85-1.56$ & 1.06 & $0.94-1.19$ \\
\hline Moderate & 1.15 & $0.56-2.37$ & 1.25 & $0.40-3.95$ & 1.03 & $0.86-1.25$ & 0.93 & $0.73-1.18$ \\
\hline Strength training & 1.58 & $0.70-3.55$ & 0.83 & $0.29-2.34$ & 0.96 & $0.76-1.22$ & 1.06 & $0.84-1.34$ \\
\hline $\begin{array}{l}\text { Watching television an average of three or } \\
\text { per day on a school day }\end{array}$ & 1.03 & $0.72-1.47$ & 0.95 & $0.39-2.32$ & 1.12 & $0.77-1.64$ & 0.99 & $0.86-1.15$ \\
\hline \multicolumn{9}{|c|}{ Attempted weight control during the preceding 30 days } \\
\hline Exercise to lose weight & 2.40 & $1.15-5.04$ & 5.03 & $3.10-8.15$ & 2.39 & $1.57-3.63$ & 2.97 & $2.13-4.15$ \\
\hline Eat less food & 3.13 & $1.29-7.64$ & 5.11 & $3.96-6.58$ & 2.54 & $2.06-3.12$ & 3.75 & $2.97-4.73$ \\
\hline Go without eating for 24 hours or more & 2.03 & $1.24-3.31$ & 1.73 & $0.68-4.36$ & 1.16 & $0.84-1.60$ & 2.09 & $1.42-3.08$ \\
\hline Take any diet pills, powder, or liquids & 8.44 & $1.26-56.66$ & 1.00 & $0.24-4.14$ & 2.10 & $1.45-3.04$ & 3.33 & $2.00-5.56$ \\
\hline Stay the same weight & 0.81 & $0.49-1.34$ & 0.83 & $0.42-1.64$ & 0.62 & $0.34-1.13$ & 0.94 & $0.62-1.44$ \\
\hline Gain weight & 0.70 & $0.31-1.59$ & 0.11 & $0.01-1.56$ & 0.10 & $0.03-0.38$ & 0.29 & $0.15-0.58$ \\
\hline
\end{tabular}

a Adjusted by student's marital status and family's standard of living.

that were associated with measures of physical activity, watching television, and attempted weight control. Adolescent boys in the LRGV who participated in sport teams were less likely $(\mathrm{OR}=0.87 ; 95 \% \mathrm{CI}=0.77-0.98)$ to be at or above the 85th percentile of BMIfor-age. Although of borderline significance, adolescent boys in the LRGV $(\mathrm{OR}=0.80 ; 95 \% \mathrm{CI}=0.63-1.02)$ and in Matamoros (OR $=0.40 ; 95 \% \mathrm{CI}=0.15-$ 1.08) were also less likely to be at or above the 85th percentile of BMI-forage if they participated in physical education classes. None of the remaining physical activity measures was associated with being at risk for overweight or with being overweight among Matamoros students.

In comparison with normal-weight girls, adolescent girls in both Matamoros and the LRGV who were at risk for overweight or overweight were more likely to try to lose weight by exercising, eating less food, or taking diet pills, powder, or liquids without a doctor's advice during the 30 days preceding the survey (Table 2). Ado- lescent girls in the LRGV who were at risk for overweight or were overweight consistently reported that they were less likely to try to gain weight $(\mathrm{OR}=0.10$; 95\% CI = 0.03-0.38).

On the other hand, adolescent boys in Matamoros who were at risk for overweight or were overweight were more likely than normal-weight boys to exercise and to eat less food in order to lose weight during the 30 days preceding the survey (Table 2). Adolescent boys in the LRGV who were at risk for overweight or were overweight were more likely to perform all five of the measures for attempted weight control. These same boys consistently reported that they were less likely to try to gain weight $(\mathrm{OR}=0.29 ; 95 \% \mathrm{CI}=0.15-0.58)$ and more likely to try to lose weight (OR = $6.40 ; 95 \%$ CI $=4.10-9.98)$. Watching television three or more hours per day on average on a school day was not statistically associated with being at risk for overweight or overweight among the girls and boys in either Matamoros or the LRGV.

\section{DISCUSSION}

This is the first study to describe overweight, physical activity, watching television, and attempted weight control among adolescents in the city of Matamoros. In addition, we compared the results from Matamoros with those from the LRGV area across the border from Matamoros. Nearly one-third of the students in Matamoros and in the LRGV are at risk for overweight or are overweight; the prevalence of at risk for overweight and overweight was based on United States criteria (21).

Using nationwide data for Mexico collected in 2000 with measured heights and weights and applying the same CDC criteria that we did in our study, del Río-Navarro et al. (22) found that $18.3 \%$ of 14 -year-old Mexican girls and $12.5 \%$ of 14-year-old Mexican boys were at risk for overweight. When restricting the analysis to the northern region of Mexico (where Matamoros is located), the prevalence of at risk for overweight 
among children 10-17 years old was $17.2 \%$ for girls and $14.9 \%$ for boys (22). In comparison with their counterparts in northern Mexico overall (23), the ninth-grade girls in Matamoros had a lower prevalence of at risk for overweight $(15.0 \%)$, and the ninth-grade boys had a similar prevalence of at risk for overweight (14.5\%).

In the LRGV the prevalence of overweight among girls (11\%) and among boys (23\%) was lower than previously reported for Hispanic adolescents in Texas (24). For eighth-grade students in Texas in 2000-2002, Hoelscher et al. (24) reported a prevalence of overweight of $16 \%$ among Hispanic girls and of $33 \%$ among Hispanic boys. A possible explanation for the lower estimates of overweight found in the LRGV compared to the Hoelscher et al. (23) findings for Texas overall may have been the self-reported heights and weights for LRGV students; in the Hoelscher et al. (23) study the students' height and weight were measured directly. Another explanation for the lower estimates of overweight found in the LRGV may be the small size of the LRGV sampling frame (21 500 students) versus that of the Hoelscher et al. (23) study (288 584 students).

The prevalence of overweight in the Matamoros girls (13.6\%) and in the Matamoros boys (20.8\%) is consistent with previously reported data $(22,24)$. In particular, for the northern region of Mexico, del Río-Navarro et al. (22) reported an overweight prevalence of $13.0 \%$ for girls and $14.7 \%$ for boys 10-17 years of age.

It is not surprising that physical education enrollment was similar for boys and girls in Matamoros and higher than it was for the LRGV students, given that the Mexican school curriculum requires a minimum of two class sessions during the school week, for at least 45 minutes each. The Matamoros boys were more likely to participate in physical activities than were the Matamoros girls. However, the Matamoros girls had a lower prevalence of overweight, which may be due to the girls' higher prevalence of attempting to maintain ideal weight through dieting. Our findings indicate that current physical activities do not decrease the likelihood of being at risk of overweight or of overweight. In the LRGV and in Matamoros the prevalences of having participated in vigorous and moderate physical activities were similar to those for Hispanic and ninth-grade schoolchildren in the United States. Dietary education, in combination with physical activity intervention programs, has shown promising results for school-based approaches to reducing overweight among youth (25-29).

Our data do not support some previous studies (30-33) where a substantial amount of time watching television was found to be a risk factor for at risk for overweight among adolescents. Our results are consistent with a meta-analysis of United States studies (34) that found that the relationship between TV viewing and body fatness among adolescents is likely to be too small to be of clinical relevance (34). Our results are also consistent with data from adolescents in Mexico City (11).

There are limitations to the approach that we used in this study. First, the use of cross-sectional data did not allow us to evaluate increasing or decreasing trends in this region; surveillance efforts are required to evaluate possible increasing rates of overweight. Studies indicate that it is likely that overweight adolescents remain overweight as they enter adulthood (11), and adulthood overweight has been shown to be associated with markedly increased risks of cardiovascular disease and type 2 diabetes $(11,35,36)$. Current data from Mexican adolescents indicate that overweight could be the basis for a growing problem of adult chronic disease (22).

A second limitation was that we conducted the survey in Matamoros during the 2002-2003 school year, two years after the survey done in the LRGV. In spite of this, the results should be comparable. Because of the lack of interventions during these two years, we did not expect any significant changes in the behavior of school- children in Matamoros. Similarly, we did not expect any significant bias in this population on the prevalence of overweight, physical activities, watching television, or measures attempting to control weight due to the lack of interventions during these two years. In addition, the data from Matamoros allowed us to adjust for nonresponse, which was not possible with the LRGV data.

Our biggest limitation was the different methods for collecting information on heights and weights in the LRGV and Matamoros. However, self-reported and direct measures of heights and weights have been found to be highly correlated (37).

In summary, we determined that overweight has become as big a problem among the Mexican adolescents as among the Mexican-American adolescents. The challenge of overcoming the extremely high prevalence of overweight or of being at risk for overweight among adolescents in the Texas/Mexico border region is immense. Interventions focusing on diet, diet education, and physical activities need to be implemented, along with evaluations of these intervention. These measures are essential for reducing the extremely high prevalence of overweight among students in this region.

Acknowledgments. This research was supported by a grant from the United States National Institutes of Health National Center on Minority Health and Health Disparities (NIH CMHD P20MD000170-019001). The authors would like to thank the principals, coordinators, teachers, and other staff in the public and private schools in Matamoros for their support of this study. The authors also thank the students from the associate degree program in nursing at the University of Texas at Brownsville; the staff from Healthy Communities of Brownsville, Inc.; the staff from The University of Texas Health Science Center at Houston School of Public Health Brownsville Regional Campus; and volunteers and staff members from the Secretaría de Educación de Tamaulipas. 


\section{REFERENCES}

1. Grunbaum JA, Kann L, Kinchen S, Ross J, Hawkins J, Lowry R, et al. Youth risk behavior surveillance-United States, 2003. MMWR Surveill Summ. 2004;53:1-96.

2. Campbell K, Waters E, O'Meara S, Kelly S, Summerbell C. Interventions for preventing obesity in children. Cochrane Database Syst Rev. 2002;CD001871.

3. Janssen I, Katzmarzyk PT, Boyce WF, Vereecken C, Mulvihill C, Roberts C, et al. Comparison of overweight and obesity prevalence in school-aged youth from 34 countries and their relationships with physical activity and dietary patterns. Obes Rev. 2005;6:123-32.

4. Uauy R, Albala C, Kain J. Obesity trends in Latin America: transiting from under- to overweight. J Nutr. 2001;131:893S-9S.

5. Hu FB, Willett WC. Optimal diets for prevention of coronary heart disease. JAMA. 2002; 288:2569-78.

6. Nelson KM, Reiber G, Boyko EJ. Diet and exercise among adults with type 2 diabetes: findings from the Third National Health and Nutrition Examination Survey (NHANES III). Diabetes Care. 2002;25:1722-8.

7. Morrill AC, Chinn CD. The obesity epidemic in the United States. J Public Health Policy. 2004;25:353-66.

8. Flegal KM, Graubard BI, Williamson DF, Gail $\mathrm{MH}$. Excess deaths associated with underweight, overweight, and obesity. JAMA. 2005; 293:1861-7.

9. United States, Department of Health and Human Services. Healthy people 2010. Available from: http://www.healthypeople.gov [Web site]. Accessed 4 May 2005.

10. United States of America, Department of Health and Human Services. Physical activity. In: U.S., DHHS. 2005 dietary guidelines for Americans. Available from: http://www. healthierus.gov/dietaryguidelines/ [Web site]. Accessed 5 May 2005.

11. Hernández B, Gortmaker SL, Colditz GA, Peterson KE, Laird NM, Parra-Cabrera S. Association of obesity with physical activity, television programs and other forms of video viewing among children in Mexico City. Int J Obes Relat Metab Disord. 1999;23:845-54.

12. Hernández B, Gortmaker SL, Laird NM, Colditz GA, Parra-Cabrera S, Peterson KE. Validez y reproducibilidad de un cuestionario de actividad e inactividad física para escolares de la ciudad de México. Salud Publica Mex. 2000;42:315-23.
13. Roberts RE, Lee ES, Hernandez M, Solari AC. Symptoms of insomnia among adolescents in the lower Rio Grande Valley of Texas. Sleep. 2004;27:751-60.

14. Sanderson M, Coker AL, Roberts RE, Tortolero SR, Reininger BM. Acculturation, ethnic identity, and dating violence among Latino ninth-grade students. Prev Med. 2004;39: 373-83.

15. Lin LI-K. A concordance correlation coefficient to evaluate reproducibility. Biometrics. 1989;45:255-68.

16. Lin LI-K. Correction to "A concordance correlation coefficient to evaluate reproducibility" (1989 V45 p255-268). Biometrics. 2000;56: 324-5.

17. Snap. Survey Software. Mercator, Professional Edition [computer program]. Version 6. Boston: Research Group Ltd.; 2003.

18. SAS Institute Inc. SAS [computer program] Version 9.1. Cary: SAS Institute Inc.; 2005.

19. Research Triangle Institute. SUDAAN Software for the Statistical Analysis of Correlated Data [computer program]. Version 9.0.0. Research Triangle Park: RTI; 2005.

20. Agresti A. Categorical data analysis. New York: John Wiley \& Sons; 1990.

21. United States of America, National Center for Health Statistics. 2000 CDC growth charts: Available from: http://www.cdc.gov/growth charts/ [Web site] Accessed 5 May 2005.

22. Del Río-Navarro BE, Velázquez-Monroy $\mathrm{O}$, Sánchez-Castillo $\mathrm{CP}$, Lara-Esqueda A, Berber A, Fanghänel G, et al. The high prevalence of overweight and obesity in Mexican children. Obes Res. 2004;12:215-23.

23. Sánchez-Castillo $\mathrm{CP}$, Pichardo-Ontiveros E, López P. Epidemiología de la obesidad. Gac Med Mex. 2004;140 Suppl 2:S3-20.

24. Hoelscher DM, Day RS, Lee ES, Frankowski $\mathrm{RF}$, Kelder SH, Ward JL, et al. Measuring the prevalence of overweight in Texas schoolchildren. Am J Public Health. 2004;94:1002-8.

25. Campbell K, Waters E, O'Meara S, Summerbell $\mathrm{C}$. Interventions for preventing obesity in childhood. A systematic review. Obes Rev. 2001;2:149-57.

26. Caballero B. Obesity prevention in children: opportunities and challenges. Int J Obes Relat Metab Disord. 2004;28 Suppl 3:S90-S95.

27. Coleman KJ, Tiller CL, Sanchez J, Heath EM, Sy O, Milliken G, et al. Prevention of the epidemic increase in child risk of overweight in low-income schools: the El Paso Coordinated
Approach to Child Health. Arch Pediatr Adolesc Med. 2005;159:217-24.

28. Gortmaker SL, Peterson K, Wiecha J, Sobol AM, Dixit S, Fox MK, et al. Reducing obesity via a school-based interdisciplinary intervention among youth: Planet Health. Arch Pediatr Adolesc Med. 1999;153:409-18.

29. Jago R, Baranowski T. Non-curricular approaches for increasing physical activity in youth: a review. Prev Med. 2004;39:157-63.

30. Dietz WH, Jr., Gortmaker SL. Do we fatten our children at the television set? Obesity and television viewing in children and adolescents. Pediatrics. 1985;75:807-12.

31. Francis LA, Lee Y, Birch LL. Parental weight status and girls' television viewing, snacking, and body mass indexes. Obes Res. 2003;11: 143-51.

32. Gordon-Larsen P, Adair LS, Popkin BM. Ethnic differences in physical activity and inactivity patterns and overweight status. Obes Res. 2002;10:141-9.

33. Gortmaker SL, Must A, Sobol AM, Peterson K, Colditz GA, Dietz WH. Television viewing as a cause of increasing obesity among children in the United States, 1986-1990. Arch Pediatr Adolesc Med. 1996;150:356-62.

34. Marshall SJ, Biddle SJ, Gorely T, Cameron N, Murdey I. Relationships between media use, body fatness and physical activity in children and youth: a meta-analysis. Int J Obes Relat Metab Disord. 2004;28:1238-46.

35. Goran MI, Ball GD, Cruz ML. Obesity and risk of type 2 diabetes and cardiovascular disease in children and adolescents. J Clin Endocrinol Metab. 2003;88:1417-27.

36. Sorof JM, Lai D, Turner J, Poffenbarger T, Portman RJ. Overweight, ethnicity, and the prevalence of hypertension in school-aged children. Pediatrics. 2004;113:475-82.

37. Strauss RS. Comparison of measured and selfreported weight and height in a crosssectional sample of young adolescents. Int J Obes Relat Metab Disord. 1999;23:904-8.

Manuscript received 1 June 2005. Accepted for publication 15 August 2005. 
RESUMEN Objetivo. Investigar si hay diferencias en las asociaciones entre la actividad física y el sobrepeso observadas en estudiantes de dos zonas colindantes en la frontera mexicanoestadounidense: estudiantes de la ciudad de Matamoros, México, y estudiantes mexicanoestadounidenses del valle a lo largo de la desembocadura del Río Bravo (VRB) en la parte sur del estado de Texas. Dada la consabida prevalencia extremadamente alta de sobrepeso en adolescentes mexicanoestadounidenses, los autores queríamos determinar si el sobrepeso también se ha convertido en un problema entre adolescentes mexicanos.

Métodos. Estudiantes de 6 escuelas $(n=653)$, que comprenden $11 \%$ de los estudiantes de noveno grado en Matamoros durante 2002-2003, y estudiantes de 13 bachilleratos $(n=4736)$, que comprenden $22 \%$ de los estudiantes de noveno grado del VRB durante 2000-2001, contestaron cuestionarios. Se llevó a cabo una regresión logística politómica a fin de calcular el riesgo de estar en riesgo de tener sobrepeso ( $\geq 85$. $^{\circ}$ percentil a $<95$. $^{\circ}$ percentil de índice de masa corporal (IMC) para la edad y el sexo) y el riesgo de tener sobrepeso ( $\geq 95 .^{\circ}$ percentil de índice de masa corporal (IMC) para la edad y el sexo), frente a un peso normal, que se asociaban con distintos grados de actividad física. En aras de la sencillez, en la clasificación del peso normal también se abarcó la insuficiencia de peso.

Resultados. Un mayor porcentaje de adolescentes estaban en riesgo de sufrir sobrepeso en el VRB (17\%) que en Matamoros (15\%). Los porcentajes de adolescentes de VRB y de Matamoros que tenían sobrepeso fueron idénticos (17\%). Los varones adolescentes en el VRB (razón de posibilidades [RP] = 0,87; IC95\% =0,77 a 0,98) que participaron en deportes en equipo tuvieron una menor probabilidad de estar en riesgo de tener sobrepeso. No se encontraron asociaciones entre ningunas de las demás categorías de actividad física por un lado, y estar en riesgo de sufrir sobrepeso o tener sobrepeso por el otro, ni en estudiantes de Matamoros ni en los del VRB.

Conclusiones. Casi una tercera parte de los estudiantes tanto en Matamoros como en el VRB está en riesgo de tener sobrepeso o tiene sobrepeso. La puesta en práctica de intervenciones para fomentar hábitos alimentarios sanos y la participación en clases de educación física y en deportes en equipo es una medida esencial para reducir la prevalencia extremadamente alta de sobrepeso observada en estudiantes a ambos lados de la frontera entre México y Estados Unidos.

Palabras clave Obesidad, peso corporal, acondicionamiento físico, adolescente, Americanos Mexicanos, México, Texas.

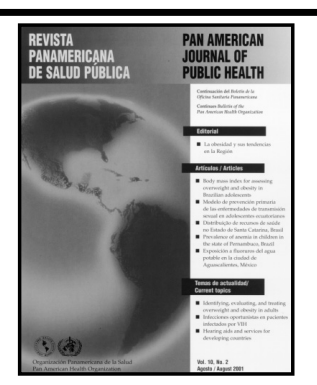

$2003 \cdot 80 \mathrm{pp}$. Código: OP 155

Precio: US\$ 18 en América Latina y el Caribe y US $\$ 25.00$ en el resto del mundo

\section{Revista Panamericana de Salud Pública. Número especial sobre la actividad física}

En este número de la Revista Panamericana de Salud Pública/Pan American Journal of Public Health se presentan informes que por primera vez exploran la magnitud del sedentarismo en Brasil, Chile, México y Perú.

En términos generales, los estudios informan de que más de dos terceras partes de la población no practican los niveles recomendados de actividad física que hacen falta para devengar beneficios de salud. Esta alta prevalencia del sedentarismo, con sus riesgos sanitarios, es especialmente alarmante a la luz de los acelerados cambios del estilo de vida en zonas urbanas que fomentan la inactividad física y el mínimo esfuerzo en todos los ámbitos de la vida: el trabajo, las tareas domésticas, el transporte y los pasatiempos.

http://publications.paho.org・Fax: (301) 206-9789・Correo electrónico: paho@pmds.com 